\title{
Analysis Improvement of Helpdesk System Services Based on Framework COBIT 5 and ITIL 3rd Version (Case Study: DSIK Airlangga University)
}

\author{
Laqma Dica Fitrani $^{1}$, R. V. Hari Ginardi ${ }^{1}$
}

\begin{abstract}
Airlangga University has a helpdesk system that is tasked to help overcome the problems related to the use of information technology facilities that can be utilized by the academic community. This system is managed by the Directorate of Information System. Currenty, there are many complaints handled by the helpdesk that make it difficult to handle problems, the escalation of problem handling is still not optimal, complaint handling is not in accordance with the time set, and still miss communication between the helpdesk and the unit responsible for completing the complaint. Based on the problems, improvement analysis of the helpdesk system services is required. The service analysis of the helpdesk system will be done using the COBIT 5 and ITIL V3 framework. Data were obtained through interviews and questionnaires distributed to RACI Chart based on domains selected which is DSS01. The data is processed to obtain the level of capability (As Is) and the expected condition (To Be), then gap analysis of these two conditions to be used as the basis of the information technology governance improvement strategy in managing the helpdesk system. The improvement plan is done by combining COBIT with ITIL V3. From this research, the current capability values at level 1 and to be values at level 4, so the gap value obtained is 3. The result of the capability value analysis and gap is used to make the recommendation of continuous improvement to achieve the to be value and the governance plan on incident management based on ITIL V3 framework.
\end{abstract}

Keywords-Capability Level, COBIT 5, Helpdesk, ITIL V3, RACI chart.

\section{INTRODUCTION}

Helpdesk is a formal organization that provides support function to users of the companies product, services, or technology[1]. The helpdesk system will succeed if the system can handle and resolve quickly and accurately every incoming complaints on hardware or software based on the difficulty level. Helpdesk at Airlangga University is responsible for handling complaints from the academic community such as students, lecturers, and staff that involved information technology services in university. This system is managed by the Directorate of Information System. Currenty, there are many complaints handled by

\footnotetext{
${ }^{1}$ Laqma Dica Fitrani and R. V. Hari Ginardi are with Departement of Informatics, Institut Teknologi Sepuluh Nopember (ITS), Surabaya, 60111, Indonesia. E-mail: Laqmadica29@gmail.com; hari@its.ac.id.
}

the helpdesk that make it difficult to handle problems, the escalation of problem handling is still not optimal, complaint handling is not in accordance with the time set, and still miss communication between the helpdesk and the unit responsible for completing the complaint.

References from previous research on the same topic of the use of COBIT and ITIL V3 framework, most of the research is still using COBIT 4.1 but some have used COBIT 5. This research is conducted on various sectors of companies such as retail companies, government-owned companies, and other private companies. There are differences in the scope of research on each company. There is a difference in the scope of research in each company. Some companies limit the scope of the object that is related to incident management, problem management, service desk, but there is also a research that covers the whole of information technology services that have been applied. The purpose of the research is to know the level of management of information technology processes in the organization and to ensure the availability of information technology support services in running the company's business processes relating to the vision and mission of the company. COBIT is a framework used as a frame of reference for measuring the capabilities level of IT processes and combined with ITIL V3 to help select the processes to be measured for capability levels[2]. COBIT implemented in conjunction with ITIL can help companies along with the development of companies that impact on the performance of human resources in its activities require the role of information technology. Measurement of information technology to each company is needed with the aim to know the applied information technology is functioning optimally and can handle the problem appropriately. Measurement of the current condition value and target value, from the measurement of the two things will result in the gap value to be analyzed. After that make recommendations that can be a guide to manage information technology support services and improve the value as expected based on the framework of COBIT and ITIL V3[3]-[6].

COBIT 5 can ensure that service management efforts are aligned with business objectives. ITIL V3 provides an explanation of best practices for how to plan, design and manage effective services[7]. The combination of these two 
frameworks is expected to be helpful in knowing effectiveness and efficiency and can create sustainable improvement guidance from helpdesk information technology services based on the results of the capability level of helpdesk information technology services. the result of capability calculation and value gap to know how far information technology governance applied in business process, how far information technology service influence to existing business process, and to know how far level of capability of management of information technology service that exist. Based on the findings of the implementation of this research, it can deliver recommendations and governance plans that can be used by the DSIK unit as a reference to provide feedback on improving the management of information technology that will come.

\section{METHOD}

This research used a combination of COBIT 5 and ITIL V3. The selection of domains is done by mapping the process of ITIL V3 with the process on COBIT 5 which is related to the problems that exist in helpdesk DSIK unit.

COBIT 5 as a reference for the process of capability calculation and targeting to be achieved then conducted gap analysis for the provision of recommendations based on ITIL V3 to support the purpose of the process.
Capability and target values were obtained from interviews and questionnaires addressed to 8 respondents selected based on RACI Chart.

1. Problem Definitions : The problem that focuses in this paper is how to give a guide for Airlangga for implementing IT Governance in incident management area.

2. Defining Solution : The solution is defining with a literature review related to papers or research related IT governance in University. Solutions build the solution are developed based on the author's experiences while working on projects related to IT governance.

3. Design and Model Development Demonstrations Design and model IT Governance for the hospital is development base on COBIT 5 framework. In this step, describe how IT governance implemented in University.

\section{RESULTS AND DISCUSSION}

DSS02 is a process that aims to provide quick and effective responses to user requests and resolutions of all types of incidents. Recover services, record and fulfill user requests and record incidents, investigate, determine, escalate problems, and resolve incidents[8].

TABLE 1.

ACHIEVEMENT LEVEL DSS02

\begin{tabular}{|c|c|c|}
\hline \multicolumn{3}{|c|}{ DSS02 - Manage Service Request and Incidents } \\
\hline & Achievement of level 0 & Criteria Met? \\
\hline DSIK Airlangga University has oper & $\begin{array}{l}\text { tional procedures standard that includes helpdesk service mechanism, handling trouble on helpdesk, } \\
\text { and feedback on helpdesk service and helpdesk service status. }\end{array}$ & $\mathbf{Y}$ \\
\hline \multicolumn{3}{|c|}{ Achievement of level 1} \\
\hline Sub Process of DSS02 & Interviews and Questionnaires & Percentage \\
\hline $\begin{array}{l}\text { DSS02-01 } \\
\text { IT-related services are available for } \\
\text { use. }\end{array}$ & $\begin{array}{l}\text { Helpdesk on DSIK has done identification and recording on helpdesk application in case of } \\
\text { incident. The Helpdesk records the name of the officer, the type of service, the origin of the user, } \\
\text { the work unit, the executing section, the problem, the problem level, the implementing officer, and } \\
\text { the solution of the problem that will be printed to print out the technical support form to be } \\
\text { submitted to the section handling the incident. }\end{array}$ & $100 \%$ \\
\hline $\begin{array}{l}\text { DSS02-02 } \\
\text { Incidents are resolved according to } \\
\text { agreed-on service levels. }\end{array}$ & $\begin{array}{l}\text { The Helpdesk only identifies and records the incident and then resolves it, there is no escalation or } \\
\text { special categorization for each incident so that the handling of this incident becomes longer. }\end{array}$ & $33.3 \%$ \\
\hline $\begin{array}{l}\text { DSS02-03 } \\
\text { Service requests are dealt with } \\
\text { according to agreed-on service levels } \\
\text { and to the satisfaction of users. }\end{array}$ & $\begin{array}{l}\text { The DSIK side always fulfills the service request by running the existing demand procedures, } \\
\text { handling incidents or service requests until closing, reporting and analyzing incidents that have } \\
\text { already occurred for inventory information in the event of a similar incident and for future } \\
\text { improvement. }\end{array}$ & $66.7 \%$ \\
\hline
\end{tabular}

\begin{tabular}{|c|c|c|c|c|c|c|c|c|c|c|}
\hline Process Name & Level 0 & Level 1 & \multicolumn{2}{|c|}{ Level 2} & \multicolumn{2}{|c|}{ Level 3} & \multicolumn{2}{|c|}{ Level 4} & \multicolumn{2}{|c|}{ Level 5} \\
\hline DSSO2 & $\begin{array}{c}\text { FALSE if Process Capability is } \\
\text { Level } 1 \text { or Higher }\end{array}$ & PA 1.1 & PA 2.1 & PA 2.2 & PA 3.1 & PA 3.2 & PA 4.1 & PA 4.2 & PA 5.1 & PA5.2 \\
\hline \multirow{2}{*}{ Rating by Criteria } & \multirow{2}{*}{ FALSE } & $67 \%$ & $50 \%$ & $50 \%$ & $20 \%$ & $17 \%$ & $0 \%$ & $0 \%$ & $0 \%$ & $0 \%$ \\
\hline & & $\mathrm{L}$ & $\mathrm{p}$ & $p$ & $p$ & p & N & $\mathrm{N}$ & $\mathrm{N}$ & $\mathrm{N}$ \\
\hline $\begin{array}{c}\text { Capability Level } \\
\text { Achieved }\end{array}$ & & 1 & & & & & & & & \\
\hline
\end{tabular}

Figure 1. Rating Scale DSS02 
TABLE 2.

TARGET CAPABILITY DSS02

\begin{tabular}{|c|c|c|c|}
\hline Process Code & Interview result & The conclusion of the interview & Target capability \\
\hline DSS02 & $\begin{array}{l}\text { Customer demand must be fulfilled according to the agreed } \\
\text { time. Incident handling should also refer to the existing } \\
\text { SLA. It requires a process equipped with clear benchmarks, } \\
\text { the number of interruptions in a given time, the time } \\
\text { required for new installation requests as well as service } \\
\text { modifications (relocation, upgrades, downgrades) }\end{array}$ & $\begin{array}{l}\text { DSIK wants the parameters that } \\
\text { can ensure consistency of } \\
\text { achievement of process results. }\end{array}$ & 4 \\
\hline
\end{tabular}

TABLE 3.

GAP VALUE OF DSS02

\begin{tabular}{cccc}
\hline \hline Process Name & Current Capability & Target Capability & GAP Value \\
\hline DSS02 Manage Service Request and Incidents & 1 & 4 & 3 \\
\hline \hline
\end{tabular}

After know the value of capability level and GAP value. Then, identification the incident management for the recommendation. Categorization involves assigning a category and at least one subcategory to the incident. This action serves several purposes. First, it allows the service desk to sort and model incidents based on their categories and subcategories. Second, it allows some issues to be automatically prioritized. For example, an incident might be categorized as "network" with a sub-category of "network outage".

This categorization would, in some organizations, be considered a high-priority incident that requires a major incident response. The third purpose is to provide accurate incident tracking.

When incidents are categorized, patterns emerge. It's easy to quantify how often certain incidents come up and point to trends that require training or problem management. For example, it's much easier to sell the CFO on new hardware when the data supports the decision.

Incident prioritization is important for SLA response adherence. An incident's priority is determined by its impact on users and on the business and its urgency. Urgency is how quickly a resolution is required; impact is the measure of the extent of potential damage the incident may cause.

The target level by helpdesk Airlangga University is level 4 where at this level helpdesk should have run IT process within definite limits and can produce stable and predictable process within specified time limit.

To achieve these levels the helpdesk of the DSIK unit is expected to have steps in handling the problem in detail and documented to determine whether an incident is considered complete or

Proceeded to a higher phase in the escalation of the incident.

1. Input incidents based on reports from users of information technology at Airlangga University which includes students, lecturers, staff, and all other academic community even it happen by technician.

2. The Helpdesk records all existing IT incidents. Then the incident management procedure must be formulated and standardized, the Procedure includes the following conditions:

a. Identify incidents
Ensure that each incident can be identified before the negative impact of existing information technology business processes at the Airlangga University is ongoing, so the failure of the operation does not occur. b. Incident Logging

All incidents must be fully recorded in the incident management by having the date, time, and including those received by the helpdesk in reports through phone, messaging, social media, email or directly delivered as the basis for the implementation of the incident handling process.

c. Incidents Categorization

In the categorization of incidents to be more accurate when recording incidents, so it is appropriate to reconcile when handling the problem. In categorization this problem will develop at the time of the incident, so this is done in multilevel incident categorization.

d. Incidents prioritization.

Having grouped the incident and understood the current level only determines how to handle the most efficient and most appropriate incident. Ensuring delegation of incident handling gets the right staff to handle it.

e. Diagnosis initiation

If the helpdesk can't complete the Incident, but there is a prospect that the helpdesk may be able to do so within the agreed time limit without the help of another support team, the analyst must inform the user by providing the incident report number and attempt to find the resolution. Furthermore, the user can know the development of solution by giving the number of complaints.

f. Incident escalation

Escalation of incidents is an act of raising the level of handling incidents. This is closely related to the results of the initial diagnosis of the incident. If a diagnosis is found of an incident that cannot be handled, an incident must be escalated. There are 2 types of escalation of incidents, namely escalation of functions and escalation of hierarchy. Function escalation is the act of raising the level of handling to one level above it. While the escalation of hierarchy is the act of raising the level of handling across the organization hierarchy to the IT manager or related business manager. 


\section{g. Investigation and diagnosis}

Ensure thorough and in-depth investigations to find the source of incident problems. Ensure investigative and diagnostic activities are carried out based on standards and meet the SLA target handling time. Ensuring the solution found is appropriate for the intended incident.

h. Resolution and recovery

When a potential resolution has been identified, it must be implemented and tested. Specific actions to take and people to be involved

i. Incident closure

The Helpdesk must carry out an inspection action on the progress of the incident completely completed and the incident may be closed by taking an action.

j. Reporting incident handling,

Ensure recap of incident handling before maintenance, Ensure incident handling reports are made as evaluation material for future handling measures.

k. Evaluation of Incident Handling.

Ensure that evaluation is undertaken on a monthly basis to improve the quality of incident handling and ensure that evaluation results can be followed up by individual management and DSIK units.

\section{CONCLUSION}

The results of the measurement process capability using PAM (Process Assessment Model) shows that the process on the DSS02 domain is still at level 1 . The target value expected by the DSIK University Airlangga is 4 . To reach level 4, Helpdesk of DSIK unit have to do some activities from incident management as recommended by the ITIL V3 guide.

\section{ACKNOWLEDGMENTS}

We express our deep sense of gratitude to unit DSIK Airlangga University for their assistance with the projects evaluation and their contribution to carry out this study. They provided helpful comments and suggestions.

\section{REFERENCES}

[1] B. Wooten, Building \& managing a world class IT help desk. Berkeley, California: Osborne/McGraw-Hill, 2001.

[2] ISACA, COBIT 5: Enabling Processes. ISACA, 2012.

[3] S. S. Tarigan and A. Tjahyanto, "Perancangan model tata kelola dukungan layanan Teknologi Informasi (TI) menggunakan framework COBIT dan ITIL pada PT. Askes (Persero) Regional VII,” in Prosiding Seminar Nasional Manajemen Teknologi XV, 2012.

[4] M. Megawati and K. Surendro, "Usulan tata kelola manajemen insiden dan masalah berdasarkan kombinsai,” in Seminar Nasional Aplikasi Teknologi Informasi (SNATI), 2012, vol. 0, no. 0.

[5] I. N. S. Saputra, "Pengukuran tingkat kapabilitas dan perbaikan tata kelola teknologi informasi berdasarkan kerangka kerja COBIT 5 dan ITIL V3 2011: Studi kasus PT. XYZ,” Universitas Indonesia, 2013.

[6] R. Wijaya and R. V. H. Ginardi, "Perancangan tata kelola service desk menggunakan kerangka kerja Information Technology Infrastructure Library (ITIL) V3 pada PT. Berlian Jasa Termina Indonesia,” in Prosiding Seminar Nasional Manajemen Teknologi XXV, 2016.

[7] UCISA, "ITIL - Introducing continual service improvement.” 2017.

[8] ISACA, COBIT Process Assessment Model (PAM) using COBIT 5. Rolling Meadows IL.: ISACA, 2013. 